\title{
A TÁRSADALMI KIREKESZTETTSÉG: A PERIFÉRIÁRA SZORULT TÁRSADALMI CSOPORTOK AZ ÁTMENET IDÖSZAKÁBAN ${ }^{1}$
}

\author{
(Social Exclusion: Social Groups on the Periphery During the \\ Transitional Period)
}

JÁSZ KRISZTINA

\begin{abstract}
Kulcsszavak:
társadalmi kirekesztés társadalmi indikátorok halmozottan szegények települési hátrány etnikai szegénység

A szerzö áttekinti a társadalmi kirekesztés vizsgálatának elméleti hátteréül szolgáló legfontosabb szociológiai irányzatokat, valamint vizsgálja a jelenség mérésére szolgáló indikátorok kidolgozásának folyamatát. A tanulmány továbbá végig követi a kirekesztett társadalmi csoportok helyzetének alakulását a rendszerváltás óta eltelt másfél évizedben. Szorgalmazza a területi szintũ szociálpolitikai tervezés reformjânak sziikségességét.
\end{abstract}

A társadalmi kirekesztés a 2000. évi Nizzai Szerződés óta széleskörủen használt fogalommá vált Európában, a jelenség azonban már az 1980-as évek óta a nyugateurópai szociálpolitikai kutatások és viták fókuszában áll. A társadalmi kirekesztés, a halmozott szegénység, a depriváció kifejezések ugyanazon társadalmi jelenség leírására szolgálnak, a kutató nézőpontja dönti el, hogy a szegénység kialakulásához vezetö folyamatot, vagy a különbözö javaktól való megfosztottságot, mint e folyamat végtermékét veszi-e részletesebben górcsỏ alá. Amennyiben a kialakuláshoz vezetö út jellemzőinek leírása a kutatás témája, akkor a társadalmi kirekesztés vizsgálatáról beszélünk.

A szegénységre vonatkozó szakirodalomban ${ }^{2}$ az empirikus vizsgálatok és módszertani polémiák vannak túlsúlyban, meglehetösen kevés a jelenségre vonatkozó klasszikus értelemben vett társadalomelméleti megközelítés. Egységes elméleti fogalomrendszer hiảnyában e dolgozat keretében csak néhány klasszikus szociológiai irånyzat rövid áttekintésére nyílik lehetőség, olyan elméleti megközelítések összegzésére, amelyek valamely módon segítik a társadalmi kirekesztésnek, mint korunk társadalma egyik tipikus jelenségének megértését.

Két alapvető elméleti irånyzat kapcsolódik a szegénység-problematikához a szociológiában: a funkcionalizmus és a konfliktuselmélet. Mindkét irányzat a társadalmi egyenlőtlenségek kialakulásának, a társadalom tagolódásának folyamatát magyarázza más-más faktorokra helyezve a hangsúlyt.

A funkcionalista megközelítés szerint a társadalmi egyenlőtlenségek kialakulásának fö oka, hogy a társadalomban sokféle, a közösség számára eltérö jelentőségủ feladatot kell ellátni, amelyet a közösség más-más módon jutalmaz (Spéder 2002). A magas iskolai végzettséget és a sajátos, az átlagember által nem birtokolt képes- 
ségeket igénylő feladatok ellátására nem mindenki alkalmas. A funkcionalista iskola jeles képviselői, Davis és Moore szerint az elöbbiekböl következően a társadalmi egyenlőtlenségek kialakulása a pozíciók eltérö fontosságának, valamint az egyes emberek nem azonos képességeinek köszönhetők.

A konfliktuselméleti iskola elméleti hátterét a marxizmus adja, mely szerint a kapitalista társadalom tagolódása a tulajdonon alapuló kizsákmányoláson alapszik. A modern társadalomban ehhez járulnak még hozzá a perifériára kerülés szempontjából fontos tényezők: a szervezeti hatalom és a képzettség, amelyek szintén jelentősen befolyásolják egyes társadalmi csoportok kiszolgáltatott helyzetbe kerülését. A szegénység e folyamatok eredőjeként alakul ki.

Mindkét elméleti megközelítés szerint a szegénység mélyebb strukturális változások következménye, és a munkaerö-piaci helyzet áll az esetek túlnyomó részében a vizsgálatok fókuszában.

Az 1980-as években az elöbbiekben vázolt funkcionalista és konfliktuselméleti megközelítések folytatásaként és továbbgondolásaként megjelentek a többdimenziós elméletek, amelyeket leginkább Geiger, Lenski és Blau munkássága fémjelez. A többdimenziós szemlélet megjelenése lehetővé tette a szegénységvizsgálatok finomítását, így megteremtődtek a feltételei a többszörösen hátrányos helyzetben élök, a deprivált helyzetúek vizsgálatának is. E szemlélet jelentősége továbbá abban rejlik, hogy a kutatók már nemcsak egyetlen faktor, a foglalkoztatás mentén próbálják leírni a szegénység kialakulásának folyamatát, hanem a társadalmi helyzet fogalmának használatával az inaktív rétegekről is próbálnak információkat gyüjteni. Ez azért fontos előrelépés, mert a szegények többsége ma már inaktív pozícióban van, tehát nem adható a szegénységröl átfogó kép e csoport vizsgálata nélkül.

Az 1980-as években Amerikában egy új fogalom jelent meg a társadalmi struktúrát elemző írásokban, az underclass fogalma. E fogalmi elnevezéssel a halmozottan hátrányos helyzetü csoportokat kívánták leírni és besorolni. Európában ugyanerre a csoportra a kirekesztett jelzőt kezdték el használni. A társadalmi kirekesztés a jóléti államokban bekövetkezett válságjelenségek elemzése, illetve az olajárrobbanás következtében bekövetkezett strukturális átrendezödések miatt és a globális kihívásokra adott nemzetállami válaszok révén került a figyelem középpontjába (Szalai 2002). A társadalmi kirekesztés fogalmának megszületése kezdetben fóként Franciaországban és Angliában az új típusú szegénység leírására szolgált, az Európai Unióban 1985-ben vezették be használatát. Az Unió történetében a kirekesztéssel kapcsolatosan a fordulópontot az 1997. évi Amszterdami Szerződés jelentette, melynek 137. cikkelye szerint a társadalmi kirekesztettség felszámolására az Európai Unió országainak átfogó stratégiára van szükségük (Fóti 2003). A szerződés jelentösége abban rejlik, hogy nemcsak deklarálta a kirekesztettség megszüntetésének fontosságát, hanem a foglalkoztatáson túl kijelölte azokat az egyéb célterületeket, ahol szintén további beavatkozásokra van szükség, például lakáshelyzet, közlekedés, kommunikáció.

A fogalom tisztázásához újabb jelentös elörelépés történt Atkinson munkássága révén, aki szerint a társadalmi kirekesztődés olyan elszigetelődési folyamat, amely 
során az egyes embereknek és társadalmi csoportoknak nincs választási lehetöségük (Fóti 2003). Míg a szegénységvizsgálatok középpontjában a jövedelmi viszonyok állnak, a kirekesztés kutatásánál több tényező egyidejü vizsgálatára van szükség.

Magyarországon a társadalmi kirekesztés fogalmi használatáról és vizsgálatának kísérleteiről csak a rendszerváltás óta beszélhetünk. Érdemes áttekinteni röviden e jelenség okait. A fő ok abban keresendő, hogy a rendszerváltást megelőzöen a szegénység nem létező fogalomnak tekintett jelenség volt Magyarországon. A rendszerváltás elött a társadalom perifériáján élöket beilleszkedési zavarokkal küzdőknek és többszörösen hátrányos helyzetüeknek titulálták, akik kizárólag saját devianciáiknak köszönhették kialakult helyzetüket (Szalai 2002). A szegénység eltitkolásának egyik legkomolyabb következménye az lett, hogy a társadalomtudósok számára nem állt rendelkezésre megfelelő nyelvezet és fogalmi rendszer a rendszerváltást követően drámai módon felszínre kerülö jelenség leírására.

A szegénység és társadalmi kirekesztődés vizsgálatok alapját képező társadalmi jelzőszámok ${ }^{3}$ kidolgozása az 1960-as évektöl csaknem két évtizeden keresztül tartott. A kutatóműhelyek létrehozásának célja az volt, hogy megoldást találjanak a szegénységgel kapcsolatos fogalmi, mérési és egyéb módszertani problémák feloldására. A legjelentősebb társadalomelméleti mühelyek a német Zaph és a skandináv iskola képviselöje, Vogel vezetésével jöttek létre. Napjainkban a szegénység és kirekesztettség mérésével kapcsolatban a kutatók számára a legnagyobb kihívást az Európai Unió integrációs folyamatainak vizsgálata, illetve az erre vonatkozó nemzetközi összehasonlító jelzőszámok kidolgozása jelenti. Magyarországon az 1970-es évek közepén Andorka Rudolf vezetésével indult el a társadalmi jelzőszámok rendszerének létrehozása a Központi Statisztikai Hivatalban. A társadalmi indikátorok felhasználásának legtipikusabb területei: az elemzés, a tervezés és a különbözö intézkedések révén bekövetkezett folyamatok monitoringja.

A szegénység és társadalmi kirekesztettség nemzetközi indikátorainak három típusát ismerjük: az elsődleges, a másodlagos és a harmadlagos indikátorokat. Az elsődleges indikátorok a társadalmi kirekesztettség legfontosabb területeit fogják át, a másodlagos indikátorok segítségével az elsődleges indikátorokat lehet magyarázni, a harmadlagos indikátorok pedig a jelenség hazai sajátosságaira mutatnak rá. A társadalmi indikátorok rendszerét a Szociális Védelmi Bizottság dolgozta ki 2001-ben. A szegénység és a társadalmi kirekesztettség vizsgálatára szolgáló hazai indikátorok tervezete az alábbi elemekböl épül fel: jövedelem, fogyasztás, lakás, halmozott szegénység, munkaerőpiac, iskola, tudás, szociális ellátórendszer, a különböző intézményekből, szolgáltatásokból való kirekesztettség, térbeli kirekesztödés és a társas kapcsolatokból való kirekesztődés. A felsorolásból is látható, hogy a tervezet objektív és szubjektív indikátorokat egyaránt tartalmaz. A korábbi gyakorlathoz képest jelentős előrelépést jelent, hogy egyéni élethelyzetek mérésére is alkalmas, valamint kistérségi és regionális szintü mutatókat egyaránt tartalmaz. Pozitívuma, hogy nagy hangsúlyt fektet a szegénység vizsgálatában a folyamat kialakulásának megismerésére, ami alapvető szempont a társadalmi kirekesztés magyarázatához. Az új rendszer segítséget kíván nyújtani a társadalmi döntéshozók számára is, 
hiszen olyan tényezök sorát tárja fel, amely megfelelö alapként szolgálhat a társadalompolitikai intézkedések kialakítása során. A társadalmi indikátorok bázisául a rendszeres adatgyüjtések és a különbözö lakossági és intézményi felvételek szolgálnak (például: életmód és időmérleg, munkaerő és lakásviszonyokra vonatkozó vizsgálatok, Háztartási Költségvetési Felvétel).

A Központi Statisztikai Hivatal a szegénység és társadalmi kirekesztés alaposabb megismerése érdekében a Társadalmi Egyenlötlenségek és Kirekesztettség projekt keretében új felvételeket indít a következö évtöl. E vizsgálat három komponensre épül, az első az úgynevezett EU-SILC vizsgálat, amely a változó életkörülmények adatfelvételt foglalja magában, a második elem a Nemzeti Program, amely a szegénység és kirekesztettség szélesebb dimenzióit fogja át (erre a vizsgálatra négy-öt évente kerülne sor), valamint célzott vizsgálatok indulnak a romák, a hajléktalanok és intézetben élök helyzetének részletes feltárására.

Az elöbbiekből látható, hogy rendkívül lényeges elemekkel bővül a közeljövöben a szegénység és társadalmi kirekesztés vizsgálata, az új indikátor-rendszer alapján tervezett vizsgálatok révén lehetőség nyílik a korábban hiányként megfogalmazott átfogó szegénység és kirekesztés-definíció megalkotására, és e két jelenség okainak és jellegzetességeinek mélyreható feltárására. További jelentősége abban rejlik a társadalmi indikátorok bővítésének, hogy a kirekesztés mérséklését célzó Nemzeti Akcióterv kidolgozásához rendelkezésre állnak majd a szükséges információk.

A szegénység cizellált vizsgálatára alkalmas indikátorok birtokában képet kaphatunk arról is, hogy mely társadalmi csoportok fosztódtak meg a felzárkózás lehetőségétöl, kik élnek a tartós szegénység szempontjából a legveszélyeztetettebb léthelyzetben.

A rendszerváltást hazánkban rendkívül mély krízis-időszak követte, amely hatalmas társadalmi tömeget érintett. Ennek legtipikusabb jelenségei közé tartozott az életszínvonal drámai mértékủ csökkenése, munkahelyek százezreinek megszünése, a többség számára a létbiztonság elvesztése. Az l. táblázatban található makrogazdasági mutatók változása jól tükrözi a rendszerváltás utáni társadalmi-gazdasági folyamatok időbeli változását, a krízis és a stabilizáció időszakait.

A rendszerváltást követö öt-hat évben az elszegényedés vált a szegénység szinonimájává (Szalai 2002). Az elszegényedés a magyar társadalom csaknem 50-70\%-át érintette. E jelenség árnyékot vetett a mély szegények helyzetére, akik már a szocialista társadalmi berendezkedés korszakában is a társadalom perifériáján éltek. A rendszerváltás elött nem lehetett róluk beszélni, helyzetüket vizsgálni, a rendszerváltást követően pedig a figyelem más tömegjelenségekre terelödött, ezért nem jutott rájuk kellő mértékủ figyelem. A politikai vezetés legfontosabb feladatává a gazdasági stabilizáció megteremtése vált, nem pedig a valódi szegénység okainak feltárása és a problémák kezelése. Az 1990-91-et követö öt-hat év alatt stabilizálódott az ország gazdasága, a hirtelen elszegényedéssel sújtott tömegek helyzete normalizálódott. A gazdaságban lezajlott pozitív folyamatok azonban nem javították a mély szegénységben élök helyzetét. Rajtuk az sem segített, hogy közben a társadalom- 
tudósok a kutatások eredményeként rengeteg új információval rendelkeztek a szegényekröl, 1993-ban megszületett a Szociális Törvény, és számos gyakorlati szakember jelent meg a humán és szociális szférában.

\section{TÁBLÁZAT}

A fö makrogazdasági mutatók alakulása, 1990-2001 (\%)

(Shaping of the Main Macro-economical Indices between 1990-2001)

\begin{tabular}{|c|c|c|c|c|c|c|c|c|c|c|c|c|}
\hline & 1990 & 1991 & 1992 & 1993 & 1994 & 1995 & 1996 & 1997 & 1998 & 1999 & 2000 & 2001 \\
\hline $\begin{array}{l}\text { Reál-GDP } \\
\text { növekedés }\end{array}$ & $-3,5$ & $-11,9$ & $-3,1$ & $-0,6$ & 2,9 & 1,5 & 1,3 & 4,6 & 4,9 & 4,4 & 5,2 & 3,8 \\
\hline $\begin{array}{l}\text { Magán- } \\
\text { fogyasztás }\end{array}$ & 3,6 & $-5,9$, & 0,0 & 1,9 & $-0,2$ & $-7,1$ & $-3,4$ & 1,7 & 4,9 & 4,6 & 4,1 & 4,0 \\
\hline $\begin{array}{l}\text { Állótőke- } \\
\text { beruházás }\end{array}$ & $-7,1$ & $-10,4$ & $-2,6$ & 2,0 & 12,5 & $-4,3$ & 6,7 & 9,2 & 13,3 & 5,9 & 7,7 & 3,1 \\
\hline $\begin{array}{l}\text { Áru- és } \\
\text { szolgáltatás } \\
\text {-kivitel }\end{array}$ & $-5,3$ & $-13,9$ & 2,1 & $-10,1$ & 13,7 & 13,4 & 7,4 & 26,4 & 16,7 & 13,1 & 21,8 & 9,1 \\
\hline $\begin{array}{l}\text { Áru- és } \\
\text { szolgáltatás } \\
\text { behozatal }\end{array}$ & $-4,3$ & $-6,3$ & 0,2 & 12,6 & 5,7 & $-0,7$ & 5,7 & 24,6 & 22,8 & 12,3 & 21,1 & 6,3 \\
\hline $\begin{array}{l}\text { Fogyasztói } \\
\text { árváltozás } \\
\text { (átlag) }\end{array}$ & 28,9 & 35,0 & 23,0 & 22,5 & 18,8 & 28,2 & 23,6 & 18,3 & 14,3 & 10,0 & 9,8 & 9,2 \\
\hline $\begin{array}{l}\text { Nettó reál- } \\
\text { bérek }\end{array}$ & $-3,7$ & $-7,0$ & $-1,4$ & $-3,9$ & 5,2 & $-12,2$ & $-5,0$ & 4,9 & 3,6 & 2,5 & 1,5 & 6,4 \\
\hline $\begin{array}{l}\text { Munkanél- } \\
\text { küliségi ráta, } \\
\text { évi átlag }\end{array}$ & 1,5 & 6,8 & 9,3 & 11,3 & 10,2 & 9,5 & 9,2 & 8,7 & 7,8 & 7,0 & 6,4 & 5,7 \\
\hline
\end{tabular}

Forrás: KSH.

A következőkben bemutatjuk, hogy mely társadalmi csoportok tekinthetők a kirekesztés kárvallottjainak (Szalai 2002), és melyek e csoport fóbb szociológiai jellemzói. Mint korábban említettuik, a társadalmi kirekesztés fogalma a szegénység egy speciális válfajának, a halmozott szegénység kialakulásának folyamataként aposztrofálható. Tehát a szegénység nagyon sokarcú állapot, az egyes szegénységtípust alkotó csoportok más-más pozíciót foglalnak el a társadalmi struktúrában, és helyzetükből való kikerülési esélyeik is differenciáltak. Ennek alapján megkülönböztetünk átmeneti és tartós szegénységet, valamint a jövedelmi-megélhetési és a halmozottan szegények kategóriáját. Ez utóbbi kategóriára használják a kutatók a mélyszegény, leszakadó és kirekesztett jelzőket egyaránt. A jövedelmi szegények életében a szegénység „csak” a mindennapi megélhetést érintő probléma (Szalai 2002). A megélhetési szegények felzárkóztatása kizárólag anyagi eszközökkel is megoldható. Ezzel szemben a kirekesztetteknél a probléma sokkal súlyosabb, hiszen számukra a szegénység már életformává vált, életük minden szféráját ez a léthelyzet hatja át. Az első csoportba elsősorban az alacsony fizetéssel rendelkező aktív dolgozók, a gyermeknevelés miatt kisebb anyagi erőforrásokkal rendelkező munkás és esetenként alkalmazott kategóriába tartozó családok, valamint a minimál- 
nyugdíjjal rendelkező, föként városi idösek tartoznak. Ök a rendszerváltást követöen elsősorban az infláció munkaeröpiacra gyakorolt hatása, valamint a társadalombiztosítási juttatások devalválódása miatt váltak jövedelmi szegényekké. Azonban ezek a csoportok lakóhelyüket, lakhatási körülményeiket, a gyermekek iskoláztatását tekintve továbbra is a többségi társadalom tagjaiként élik mindennapjaikat. Ök alkotják a mai magyar társadalom egytizedét. Ezzel szemben a kirekesztettek ahogy elnevezésükböl is következik -, szinte teljesen elszakadtak a társadalomtól. Közös jellemzöjük, hogy szegénységük elsösorban nem a rendszerváltás következménye, hanem adott esetben évtizedekre nyúlik vissza. Társas kapcsolataik rendkívül beszükültek, csak a hasonló helyzetben élőkre korlátozódnak. Ök a lepusztult lakótelepek, az elhagyott tanyák, a feltört lakások lakói. Sajátos intézményrendszer alanyai: gyermekeik túlnyomórészt kisegítő iskolákba járnak, ők azok, akik szinte kizárólag az önkormányzattól kapott jegyeket beváltva a szociális diszkontboltokban vásárolnak, és belölük rekrutálódik a fekete piacon megjelenő kiszolgáltatott helyzetben lévő munkavállalók többsége. A rendszerváltás elött föként ezekböl a családokból kerültek ki az ingázók, az építỏ- és a nehézipar foglalkoztatottjai, akik a rendszerváltás után felszámolódott másfélmillió munkahely megszünésekor szinte 100\%-ban elveszitették a munkájukat. Ezek a munkavállalók munkájuk elvesztésével nemcsak a megélhetési forrásuktól fosztódtak meg, hanem megszünt számukra a különbözö szociális és oktatási intézményekhez való kapcsolódás lehetősége is. Belölük rekrutálódik a mai nagyvárosi hajléktalantömegek legnagyobb hányada.

A kirekesztödés nem csak ezt a csoportot érintette. A mélyszegények táborát növelték a különbözö állami intézményekböl kikerülö, társadalmi kapcsolatokkal nem rendelkező emberek is, így az állami gondozottak, a tartós egészségügyi ellátásban részesülök, a börtönböl kiszabadultak. Ezek azok az egyének, akik szinte egyáltalán nem rendelkeznek családi háttérrel. A családi háttér hiánya önmagában is rendkívüli módon megnöveli a kirekesztetté válás kockázatát (Szalai 2002). Önmagában azonban a család megléte nem jelenti ,akadályát” a mélyszegénnyé válásnak. A családi kapcsolatok szoros érzelmi kötelékeken alapuló volta szolgálhat csak védelmül a kirekesztődés ellen.

A kirekesztettek vizsgálatára különböző mérési módszerek állnak rendelkezésre, halmozott szegénységüket öt mutató mentén vizsgálják, amelyek a következök: jövedelmi szegénység, fogyasztási szegénység, szubjektív szegénység, lakásszegénység és lakáskomfort-szegénység (Fóti 2003). Azokat az egyéneket, illetve családokat tekintik kirekesztetteknek, akik az öt dimenzió közül legalább háromban érintettnek bizonyulnak. Magyarországon a helyzet a lakásszegénység és a lakáskomfort szegénység terén a legsúlyosabb. A 2000. évi adatok szerint a háztartások több mint $40 \%$-ában nem fordult elő a szegénység egyetlen dimenzióban sem, halmozott szegénységben viszont a lakosság 10\%-a érintett (2. táblázat). 
Jász Krisztina: A társadalmi kirekesztettség:

a perifériára szorult társadalmi csoportok az átmenet időszakában.

Tér és Társadalom, 18. 2004. 3. 43-56. p

TÉT XVIII. évf. 2004 a 3

A társadalmi kirekesztettség ...

2. TÁBLÁZAT

A szegénység halmozódása a háztartásokban

(The Accumulation of Poverty in Households)

\begin{tabular}{|c|c|c|c|}
\hline \multirow{2}{*}{ A háztartások szegénységének típusa és kapcsolódása } & 1998 & 1999 & 2000 \\
\hline & \multicolumn{3}{|c|}{ országos aránya \% } \\
\hline Nincs egyféle szegénység sem & 28,3 & 41,5 & 42,9 \\
\hline Csak egyféle szegénység jellemző, ebböl: & 34,1 & 30,9 & 30,4 \\
\hline - csak jövedelmi szegénység van & 3,7 & 4,1 & * \\
\hline - csak fogyasztási szegénység van & 7,2 & 10,1 & \\
\hline - csak szubjektív szegénység van & 16,3 & 6,5 & \\
\hline - csak lakásszegénység van & 0,9 & 5,4 & \\
\hline - csak lakáskomfort-szegénység van & 5,9 & 4,9 & \\
\hline Kétféle szegénységtípus van & 23,8 & 15,1 & 14,3 \\
\hline Háromféle szegénységtípus van & 9,4 & 7,3 & 6,7 \\
\hline Négyféle szegénységtípus van & 2,7 & 3,9 & 2,9 \\
\hline Ötféle szegénységtípus van & 1,2 & 1,2 & 1,5 \\
\hline Együtt & 100,0 & 100,0 & 100,0 \\
\hline
\end{tabular}

* Módszertani megfontolások miatt, a szegénység jellemzöinek szigorítása eredményeként hiányos az adatsor.

Forrás: KSH, Háztartási Költségvetési Felvétel, 1998; 1999; 2000.

Ha a halmozott szegények 1,1 millió fős tömegéhez hozzáadjuk még a hajléktalanok számát, ami körülbelül 50-80 ezerre tehetö, illetve az intézményi háztartások szegényeit, akkor elmondható, hogy a magyar társadalom 12-13\%-a kirekesztettként él.

A következőkben a 2003. évi UNDP jelentésben található adatok és elemzés alapján vázoljuk a kirekesztett egyének és családok háztartásainak föbb jellemzőit. Demográfiai szempontok alapján véve górcső alá a mélyszegények csoportját, látható, hogy sok közöttük az idős, egyedülálló ember. A 70 éves, illetve annál idösebb háztartásfővel rendelkező családok alkotják a mélyszegények egyharmadát. A gyermekek közül minden ötödik halmozottan szegény, ami annak a következménye, hogy a nagycsalád nagyon megnöveli a kirekesztettség kockázatát, tehát a mélyszegény kiskorúak többsége sokgyermekes szülők gyermeke.

A kirekesztett családok családfőinek nagy része munkanélküli és csak alapfokú iskolai végzettséggel rendelkezik. A lakáskörülményekre jellemző, hogy jóval kisebb és rosszabb állagú lakásokban élnek, mint a magyar átlag. A háztartások felében nincs vezetékes víz és fürdöszoba, az otthonok kétharmada egészségtelen.

A kirekesztettségben élő családok kiadásaik több mint felét élelmiszerre költik, 20\%-át pedig a lakás fenntartására. Ruházkodásra, lakásfelszerelésre, müvelődésre, szórakozásra szinte egyáltalán nem áll rendelkezésre forrás a családi költségvetésükben. Ezek hiányában nem nyílik lehetőségük a többségi társadalom életébe való bekapcsolódásra. Megfelelö ruházat hiányában, előnytelen külsővel minimálisra csökkennek az esélyeik a munkaerőpiacra való visszakerülésre, ügyeik intézésére, hátrányokat szenvednek gyakorlatilag az élet minden területén. Érdekeik megfelelö szintủ artikulációjának igazi gátja azonban alacsony iskolai végzettségük. 
A mélyszegények alig rendelkeznek tartós fogyasztási cikkekkel, leromlott állapotú lakásokban, tipikus szegényövezetekben élnek. A kirekesztett családok gyermekei számára nem nyílik lehetöség a továbbtanulásra, ami elörevetíti annak kockázatát, hogy felnőttként is kirekesztettként fognak élni.

A leszakadók helyzetét tovább súlyosbítja az a tény, hogy minden harmadik kirekesztett háztartásban találunk tartósan beteg családtagot. A magyar háztartásoknál átlagosan minden ötödik esetben találkozunk ezzel a problémával.

A kirekesztődés kialakulásának van még két olyan kockázatnövelö eleme, amely nem az egyéni sors vagy a családi háttér következménye. Az egyik ilyen faktor a kutatási témánk szempontjából kiemelt fontosságú települési hátrány, a másik mélyszegénységet generáló tényező az etnikai származás.

A szegénység kockázatában 1990 elött a földrajzi elhelyezkedés kevésbé volt meghatározó tényező. A rendszerváltás utáni második évben Budapest és a falvak között a szegénységrátában csupán kétszeres volt az eltérés, 1998-ra ez a differencia tízszeressé nött (Spéder 2002). Az 1990-es évek elején csak az Északkeletmagyarországi régió mutatója volt kiugróan magas, az akkori átlag másfélszerese, majd hat év múlva kétszerese lett az 1998. évi átlagnak, és csaknem tízszerese a budapesti rátának. Ma már az eltérő típusú településen lakókat óriási különbségek jellemzik. Megállapítható, hogy a tartósan szegények föként falvakban és kisvárosokban, valamint föként az ország északkeleti részében laknak. Budapesten és a Dunántúlon nem számottevő a tartósan szegények aránya. Az átmenetileg szegények is a fejletlenebb Kelet-és Észak-magyarországi régiókban élnek leginkább, de érdekes adat talán -, hogy településtípus alapján elsősorban a megyeszékhelyekre koncentrálódnak. A falusiak jövedelmekben való lemaradása az adatokból jól nyomon követhetö. Azokon a területeken, ahol a lakosság még képes az önellátásra, ott a jövedelmi különbségek, például a fővárosi jövedelmi szegényekhez képest, mérsékeltebben jelentkeznek. A kirekesztettek helyzetén azonban az önellátás nem segít számottevő mértékben.

$\mathrm{Az}$ országon belüli szegénység és kirekesztettség szempontjából releváns információkkal szolgál a humán fejlettségi mutató, az az a HDI-index. A HDI-index négy fö összetevőből áll, amelyek az alábbiak:

- az oktatásban megszerzett tudás,

- az egy lakosra jutó GDP,

- az életszínvonal,

- az élethossz, amelyet a születéskor várható élettartam mutatójával mérnek (Fóti 2003).

A HDI-re kapott értékek 0-1 között helyezkednek el, az 1 közeli értékek jellemzik a fejlettebb területi egységeket. Magyarország HDI-indexe 0,817 , amellyel a világranglista 43. helyén áll.

Magyarországon 1999-ben végeztek HDI-index számítást a megyékre és a fővárosra (Fóti 2003). A megyei értékek meghatározásánál is felmerül az a módszertani probléma, ami általában véve is megnehezíti a szegénység és kirekesztettség területi 
dimenziók mentén történö vizsgálatát, ez nem más, mint a területi mutatók korlátozott volta. A területi információk beszerzése azért problematikus, mert a népesség főbb jellemzőiröl csak a népszámlálások nyújtanak információt. A GDP esetében lévén, nem állnak rendelkezésre területi árindexek -, csak becsült adatokkal dolgozhatnak a kutatók. ${ }^{4}$

A régiókra vonatkozó értékek a megyei adatok népességgel súlyozott átlagai (3. táblázat).

\section{TÁBLÁZAT}

A humán fejlettségi mutató (HDI) megyei differenciáltsága 1999-ben (Differences in the Human Development Index on a County Level in 1999)

\begin{tabular}{|c|c|c|c|c|c|c|}
\hline \multirow[b]{2}{*}{ Megye, régió } & \multirow[b]{2}{*}{$\begin{array}{l}\text { Népes- } \\
\text { ség } \\
\text { (ezer fö, } \\
2000 \text { ) }\end{array}$} & \multirow[b]{2}{*}{ HDI99 } & \multicolumn{4}{|c|}{ A HDI alapelemei } \\
\hline & & & $\begin{array}{l}\text { Születés- } \\
\text { kor várha- } \\
\text { tó élettar- } \\
\text { tam }\end{array}$ & $\begin{array}{l}\text { Írni- } \\
\text { olvasni } \\
\text { tudók }\end{array}$ & $\begin{array}{l}\text { Összevont } \\
\text { iskolázott- } \\
\text { sági mutató }\end{array}$ & $\begin{array}{c}\text { Egy } \\
\text { lakosra } \\
\text { jutó GDP } \\
\text { (PPP,USD) }\end{array}$ \\
\hline Budapest & 1812 & 0,866 & 71,6 & 99,7 & 80,3 & 20400 \\
\hline Pest & 1033 & 0,790 & 70,2 & 99,0 & 63,3 & 8700 \\
\hline \multicolumn{7}{|l|}{ Közép- } \\
\hline Magyarország & 2845 & 0,838 & & & & \\
\hline Fejér & 426 & 0,821 & 70,7 & 99,5 & 70,5 & 12200 \\
\hline Komárom-Esztergom & 310 & 0,805 & 70,4 & 99,5 & 73,4 & 8900 \\
\hline Veszprém & 373 & 0,805 & 71,4 & 99,6 & 70,7 & 8500 \\
\hline Közép-Dunántúl & 1109 & 0,812 & & & & \\
\hline Győr-M.-Sopron & 424 & 0,841 & 72,1 & 99,7 & 74,2 & 14000 \\
\hline Vas & 266 & 0,823 & 70,5 & 99,6 & 71,3 & 12600 \\
\hline Zala & 293 & 0,813 & 70,7 & 99,5 & 75,2 & 9600 \\
\hline Nyugat-Dunántúl & 983 & 0,827 & & & & \\
\hline Baranya & 401 & 0,798 & 70,0 & 99,3 & 72,7 & 8300 \\
\hline Somogy & 330 & 0,789 & 70,2 & 98,9 & 71,2 & 7400 \\
\hline Tolna & 244 & 0,805 & 70,1 & 98,6 & 73,8 & 9500 \\
\hline Dél-Dunántúl & 975 & 0,797 & & & & \\
\hline Borsod-A.-Zemplén & 730 & 0,788 & 69,6 & 98,8 & 75,2 & 7200 \\
\hline Heves & 323 & 0,800 & 70,8 & 99,2 & 75,4 & 7700 \\
\hline Nógrád & 217 & 0,776 & 70,2 & 98,7 & 71,2 & 5900 \\
\hline Eszak- & & & & & & \\
\hline Magyarország & 1270 & 0,790 & & & & \\
\hline Hajdú-Bihar & 542 & 0,797 & 70,6 & $\overline{99,1}$ & 73,7 & 7700 \\
\hline Jász-N.-Szolnok & 412 & 0,789 & 69,7 & 98,8 & 75,1 & 7200 \\
\hline Szabolcs-Sz.-Bereg & 570 & 0,773 & 69,3 & 98,9 & 72,0 & 5900 \\
\hline Észak-Alföld & 1524 & 0,786 & & & & \\
\hline Bács-Kiskun & 532 & 0,796 & 70,7 & 99,1 & 73,2 & 7500 \\
\hline Békés & 392 & 0,796 & 70,8 & 99,5 & 73,8 & 7300 \\
\hline Csongrád & 418 & 0,815 & 70,8 & 99,5 & 78,7 & 9200 \\
\hline Dél-Alföld & 1342 & 0,802 & & & & \\
\hline Magyarország & 10043 & 0,817 & 70,6 & 99,3 & 75,0 & 10700 \\
\hline
\end{tabular}

Forrás: Fóti 2003. 
$\mathrm{Az}$ adatok ebben az esetben is alátámasztják a föváros kimagasló fejlettségét. A Közép-magyarországi régió $\mathrm{HDI}$-indexe is jóval meghaladja az országos átlagot. Az adatok mind a régiók, mind a megyék szintjén a nyugati országrész előnyét tükrözik. A régiók közül a Nyugat-magyarországi régió fejlettsége meghaladja az országos átlagot, de a megyék rangsorában is a nyugati országrész megyéi (Győr-MosonSopron, Vas) állnak az élen. Melléjük zárkózik még fel Fejér megye a Középdunántúli régióból. Az ország keleti és északi térségeiből csak Csongrád megye közelít az országos átlaghoz, ami főként Szeged dinamikus gazdasági fejlődésének és oktatási központ funkciójának következménye. A legkedvezőtlenebb helyzetủ a régiók HDI-indexe alapján is az Észak-magyarországi és az Észak-alföldi régió. E régiókban találhatók a legalacsonyabb indexértékekkel rendelkező megyék: Nógrád és Szabolcs-Szatmár-Bereg. A Dunántúlon szembetủnő a Dél-Dunántúl hátránya a nyugati országrész fejlett térségeihez képest. Baranya aprófalvas térségei által generált kedvezötlen helyzetet még a fejlett régióközpont, Pécs sem tudja mérsékelni. A Dél-dunántúli régió megyéi közül Tolna értékei meglehetősen magasak, amely a paksi atomerőmü megyei GDP-re gyakorolt hatásának tudható be.

A táblázat adataiból látható, hogy a humán fejlettségi mutató értékei is leképezik a más profilú területi kutatások eredményeit. A perifériákon a helyzet változatlan, a területi hátrányok nem mérséklődtek számottevően. A települési hátrány, mint arra korábban már érintőlegesen történt utalás, úgynevezett kollektív hátrány (Szalai 2002) a társadalmilag kirekesztettek számára. A városok és a falvak közötti óriási különbségek létrejötte részben az eröltetett szocialista iparosításnak, másrészt az ország föként határ menti régióit érintő tudatos visszafejlesztési politikának a következménye. Az 1945 után kezdődött és a hetvenes években csúcspontjára jutott folyamatok a lakosság munkaerő-piaci helyzetét alapvetően befolyásoló infrastrukturális különbségeket eredményeztek, mely helyzet alapvetően befolyásolta jövedelmi viszonyaikat, valamint közvetetten kihatott érdekérvényesítő képességeikre és társadalmi integrációba való bekapcsolódásuk esélyeire is. A rendszerváltás végleg a mélyszegénység állapotába juttatta az apró zárványtelepülések lakóit, akik tömegével veszítették el munkájukat. A településeken sok esetben a legalapvetőbb szolgáltatásokat sem találjuk meg, nem müködnek a különbözö oktatási intézmények, nincs egészségügyi ellátás. Az ingatlanok elértéktelenedése miatt a zárt aprófalvak, valamint a depressziós, volt ipari körzetek lakói számára lehetetlenné vált a mobilitás. A kirekesztettségből való kitörésük csak nagyon összehangolt, számos területet érintő integrált fejlesztési programok eredményeként valósítható meg, saját - gyakorlatilag nem létező - erőforrásaikból képtelenek erre.

Az alábbi térkép négy kategória mentén ábrázolja Magyarország településeit, amelyek alapján jól nyomon követhetök hazánk leginkább periférikus területei (a sötét foltok jelzik a leginkább leszakadó, periférikus térségeket) (1. ábra). 


\author{
1. ÁBRA \\ Hátrányos helyzetü települések, 2001 \\ (Deprived Settlements, 2001)
}

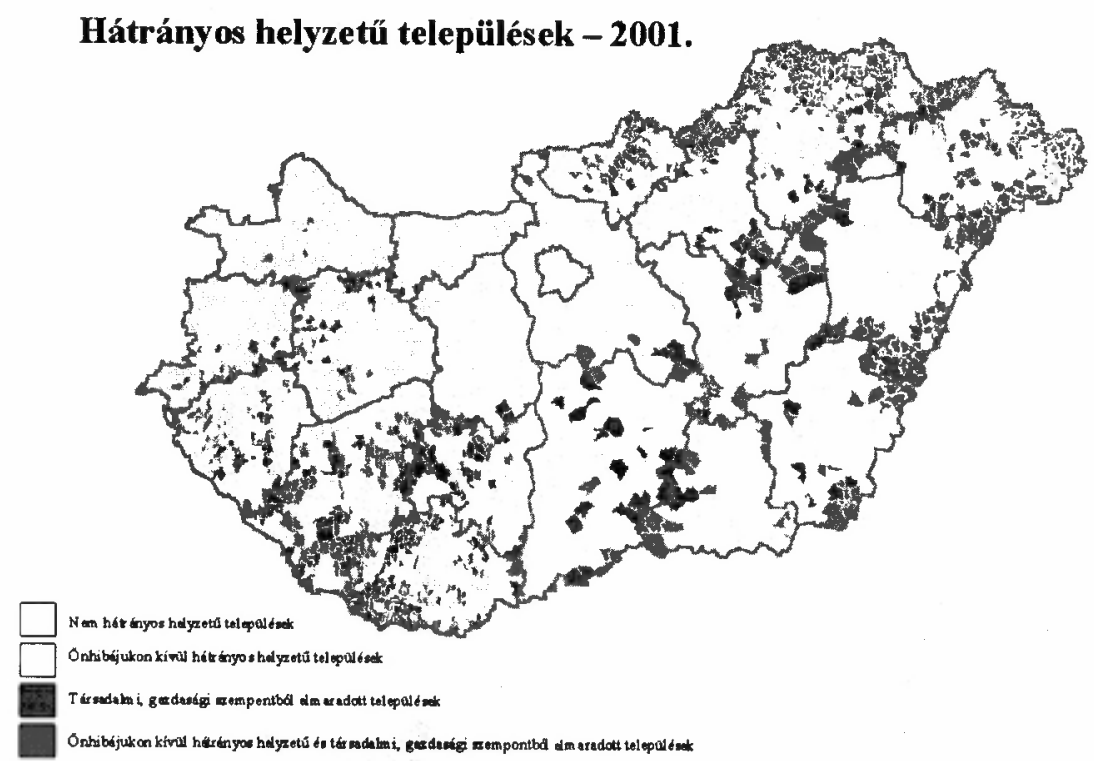

Forrás: Sziklai 2003.

A kirekesztés másik forrása, amely nem az egyéni sors, illetve a családi háttér által determinált, tehát szintén kollektív faktor, az etnikai szegénység, amely Magyarországon a cigány lakosság kétharmadát sújtja. Az elöbbiekben vázolt területi egyenlötlenségek és abból fakadó hátrányok, valamint az etnikai szegénység között szoros összefüggés áll fenn. Az ország leginkább kirekesztettnek tekinthető csoportja az aprófalvas térségek és a magas munkanélküliséggel sújtott volt nehézipari központok alkotta depressziós térségek roma lakossága. A rendszerváltás elött, a kormányzat kényszerasszimilációs politikája bár magán viselte a totális rendszerek sajátosságait, mégis ezen időszakban a romák számára lehetỏvé vált egyfajta limitált felzárkózás a többségi társadalom tagjaihoz (Szalai 2002). Megindult iskoláztatásuk, szakmát tanultak, munkahelyhez, sok esetben lakhatási lehetőséghez jutottak. A nyolcvanas években e folyamatok eredményeként vált normává számukra a gyermekek iskoláztatása, a szakmatanulás és a születésszabályozás. A rendszerváltás ezt a pozitív tendenciát törte meg. A tömeges elszegényedés közepette a létbizonytalanságba került tömegek számára a romák számos esetben bủnbakként aposztrofálódtak, és ha látensen is, de megfogalmazódott egyfajta igény a többségi társadalom tagjai részéröl korábbi helyzetükbe való visszataszításukra. A hátrányos helyzetü kistelepüléseken a meglehetősen limitált szociális juttatásokért harc indult a romák és nem romák között. Kirekesztettségük érzékeltetésére álljon itt néhány 
adat: a romák szegénységi rátája hétszerese, a tartós szegénység tekintetében csaknem tízszerese a nem romákénak. A cigány származású embereknek csupán egyötöde nem volt még élete során szegény (Spéder 2002).

Összefoglalóan elmondható, hogy a rendszerváltás alapvetően a foglalkoztatás terén okozott drámai változásokat a magyar társadalomban, amely az 1990-es évek derekán tömeges elszegényedéshez vezetett, melynek mértéke 1995-97 között volt a legmagasabb. A magyar társadalom legmagasabb szegénységi kockázattal rendelkező csoportjait a gyermekek, a gyermeküket egyedül nevelő szülők, a három és több gyermekes családok, az alacsony iskolai végzettségủek, a tartós munkanélküliek, a falun élők és a roma emberek alkotják. A területi különbségek számottevőek, a hátrányos helyzetü depresszív térségekben nem megfelelöen müködnek a szociális feszültségek kezelésére hivatott intézmények, amely elsősorban a települések kedvezőtlen gazdasági helyzetének következménye (A szociális terület... 2002).

A társadalmi kirekesztés mérséklése, a halmozottan hátrányos helyzetűek életkörülményeinek javítása az egyik legsürgetőbb össztársadalmi feladat, amely számos színtéren igényel reformokat. Elöször szót kell ejtenünk az európai uniós csatlakozásunkból fakadó kötelezettségeink teljesítésére. Mint arra a bevezetöben már utaltunk, az 1997. évi Amszterdami Szerződés óta a társadalmi kirekesztés az egyik leggyakrabban hivatkozott szó az Unióban. Jelenleg érvényben van a leghátrányosabb helyzetủ társadalmi csoportok felzárkóztatását célzó uniós szintű együttműködés, melynek egyik legfontosabb eszköze a foglalkoztatáspolitikát érintő nyílt koordinációs rendszer. Az EU célkitüzéseket fogalmaz meg a kirekesztettség mérséklésére vonatkozóan, amelyek be kell, hogy épüljenek minden tag- és csatlakozni kívánó ország nemzeti és regionális politikájába. A tagországok kétévente nemzeti cselekvési terveket készítenek, mutatókat dolgoznak ki a társadalmi kirekesztettség mérésére, valamint felülvizsgálják és értékelik a cselekvési tervet.

A társadalmi kirekesztődés elleni stratégia minél sikeresebb megvalósítását a 2002. január 1-jétöl életbe lépett Közösségi Akcióprogram is segíti, amelyhez Magyarország is csatlakozott 2002 júliusában. Fontos fejlemény, hogy a Magyar Kormány 2003-ban elkészítette a társadalmi beilleszkedésre vonatkozó Közös Memorandumot, amely a legfontosabb szakmapolitikai intézkedéseket és irányokat tartalmazza. A Memorandum elfogadását követően hazánknak el kell készítenie az első társadalmi kirekesztés elleni nemzeti cselekvési tervét is.

A társadalmi kirekesztés problematikája, a jelenség rendkívủl komplex jellege elörevetíti azt a tényt, hogy mérséklése és megszüntetése csak akkor lehetséges, ha megtörténik a különbözö szakmapolitikai döntések és az e célra fordítható források elosztásának összehangolása. E folyamatban a területfejlesztés szereplöire számos feladat hárul. Ezt indokolja az a tény is, hogy ma már világosan látszik, elengedhetetlenül szükség van a területi szintủ szociálpolitikai tervezés reformjára. Ezt több tény is indokolja, egyrészt az uniós csatlakozás révén megnyíló új forrásokhoz való hozzájutás metódusa, a tervezett közigazgatási reform, az egyes ágazatok közötti partnerségi viszonyok erösítésének szükségessége, továbbá a szociális ágazat hatékonyabb feladatellátásának igénye. A közigazgatási reform következményeként a 
szolgáltatásszervezés két kiemelt területi szintje a kistérség és a régió lesz. Kistérségi szinten fontos elörelépést jelentett mind a területi szintü tervezés, mind pedig a tárcák közötti partnerség szempontjából a kistérségi szociális felzárkóztató programok bevezetése, melynek keretében mind az ESZCSM, mind pedig a programba bevont kistérség által érintett megye területfejlesztési tanácsa három éves időszakra forrásokat biztosít a kistérséget alkotó településeken elsősorban a hiányzó alapellátási formák megteremtésére. A programon belül különösen preferáltak a társulások formájában megvalósítani kívánt projektek. Ez a gyakorlat mindenképpen folytatandó a jövőben is. Regionális szinten is elengedhetetlenül fontos a szociálpolitikai tervezés meghonosítása, amelyet egyrészt a Strukturális Alapokhoz való hozzáférés feltételeinek megteremtése indokol, másrészt pedig a regionális fejlesztési tanácsoknál rendelkezésre álló támogatásokhoz való hozzájutás tesz aktuálissá. A területfejlesztési intézményrendszer 1999. évi reformjának eredményeként létrejött regionális fejlesztési tanácsok mintájára szükséges a regionális szociálpolitikai tanácsok létrehozása is. A szociális terület regionalizációja során elkerülendỏ számos olyan hiba, amelyet a szegénység és kirekesztettség kutatói a szociális ellátások települési szintủ decentralizációjával kapcsolatban rónak fel. Nagyon fontos, hogy a leosztott feladatok mellé kellö mértékủ elosztható forrás is rendelkezésre álljon a regionális intézmények számára, ne csak a parlamenti választások idején helyeződjenek feladatok ellátására szolgáló források a decentralizált szintekre, mint ahogy ez jelenleg például Csehországban történik a regionalizált szociális szolgáltatásszervezés terén.

A társadalmi kirekesztés elleni küzdelem csak akkor lehet igazán hatékony, ha a területfejlesztési politikákban is fontos szempontként jelenik meg a társadalmi egyenlötlenségek csökkentésének szükségessége. Olyan támogatáspolitikára van szükség, amely lehetővé teszi a helyi társadalom erőforrásainak mozgósítására irányuló kezdeményezések támogatását. A területfejlesztés és a vidékfejlesztés szereplöinek pedig együtt kell müködnie a falu hagyományosan valaha meglévő önsegélyező folyamatainak visszaállitásában. ${ }^{5}$

Megítélésünk szerint a társadalmi kirekesztés 2004. évtöl induló új, a területi dimenziókat is hangsúlyosan magába foglaló vizsgálata számos új információt fog szolgáltatni a területi egyenlötlenségek okairól, jellegzetességeiről, valamint közelebb viszi a kutatókat a periféria-problematika alaposabb megismeréséhez is.

\section{Jegyzetek}

${ }^{1}$ A tanulmány a Dr. Csatári Bálint által vezetett, Területi konfliktusok és változásaik a periférián címủ kutatási program keretén belül készült 2003-ban.

${ }^{2}$ Az elméleti áttekintés Spéder Zsolt: A szegénység változó arcai címü (2002) könyve releváns fejezetének felhasználásával készült.

${ }^{3}$ A társadalmi jelzőszámok áttekintése Monostori Judit, a KSH munkatársa 2003. november 6-án, a társadalmi befogadás-kirekesztés hatásairól szóló mühelybeszélgetésen tartott elöadása anyagának felhasználásával készültt.

4 Számos más apróbb módszertani probléma is felmerül a HDI-index meghatározása során, de ezek témánk szempontjảból nem bírnak túl nagy jelentỏséggel, ezért nem térünk ki rájuk részletesen. 
5

A tárcák elött álló feladatok áttekintése részben Sziklai István, az ESZCSM munkatársa a 10 éves a Szociális Törvény címủ konferencián elhangzott elöadásának felhasználásával készültt.

\section{Irodalom}

Ferge Zs.-Tausz K.-Darvas Á. (2002) Küzdelem a szegénység és a társadalmi kirekesztettség ellen. Esettanulmány Magyarországról. International Labour Office, Budapest.

Fóti K. (szerk.) (2003.) A szegénység enyhitéséért. Helyzetkép és javaslatok. Országjelentés a humán fejlettségrỏl az UNDP program keretében, MTA Világgazdasági Kutató Intézet, Budapest.

Füleki D. (2001) A társadalmi kirekesztés és befogadás indikátorai. - Szociológiai Szemle. 2. 84-95. o.

Havasi É. (2002) Szegénység és társadalmi kirekesztettség Magyarországon. - Szociológiai Szemle. 4. 51-72. o.

Monostori J. (2003) A szegénység és társadalmi kirekesztés indikátorai. Konferencia elóadás. 2003. november 6. Nemzeti Család- és Szociálpolitikai Intézet, Budapest.

Spéder Zs. (2002) A szegénység változó arcai. Andorka Rudolf Társadalomtudományi Társaság Századvég Kiadó, Budapest.

A szociális terület helyzetelemzése, 1994-2001. (2002) ESZCSM háttéranyag a Nemzeti Fejlesztési Tervhez. Budapest.

Szalai J. (2002) A társadalmi kirekesztés egyes kérdései az ezredforduló Magyarországán. - Szociológiai Szemle. 4. 34-51. o.

Sziklai I. (2003) Az átmenet társadalmi, gazdasági kihívásai. Konferencia előadás. 10 éves a Szociális törvény c. konferencia. 2003. december 5. Nemzeti Család- és Szociálpolitikai Intézet, Budapest.

\section{SOCIAL EXCLUSION: SOCIAL GROUPS ON THE PERIPHERY DURING THE TRANSITIONAL PERIOD KRISZTINA JÁSZ}

The author reviews the most important sociological schools that could be considered as a theoritical background for the examination of social exclusion. She also examines the process of elaborating social indicators that can be used for measuring exclusion. Furthermore, the study follows the shaping of the situation of socially excluded groups during the last one and a half decades after the change of the regime. She stresses the need of reform in sociopolitical planning on a regional level. 